\title{
ANALISIS KEMAMPUAN KOMUNIKASI MATEMATIS SISWA KELAS VIII PADA MATERI HIMPUNAN
}

\author{
Siti Aminah ${ }^{1)}$ Tommy Tanu Wijaya ${ }^{2)}$ Devi Yuspriyati ${ }^{3)}$ \\ 1,2,3Pendidikan Matematika, IKIP Siliwangi \\ E-mail: ${ }^{1)}$ sitiami1011@ gmail.com
}

\begin{abstract}
This study aims to examine and analyze about: (1) students are able to relate real object, picture, and diagram to mathematics ideas, (2) students are able to explain mathematics ideas, situation, and relation, verbal or written by using real object, picture, graphic, and algebra, (3)students are able to state daily life situation into mathematical language or symbol, (4)students are able to make conjecture, to formulate argument, to formulate definition and generalization, (5) students are able to make explain or make question about mathematic. This study was designed qualitative method. The population in this research is VIII grade junior high school in Cimahi. Based on the results and discussion, students ability to make conjecture, to formulate argument, to formulate definition and generalization are bad. students ability to state daily life situation into mathematical language or symbol are bad. Students ability torelate real object, picture, and diagram to mathematics ideas is bad. students ability to explain mathematics ideas, situation, and relation, verbal or written by using real object, picture, graphic, and algebra is bad.
\end{abstract}

Keywords: Mathematical Communication student ability

\begin{abstract}
Abstrak
Penelitian ini bertujuan untuk menelaah dan menganalisis mengenai: (1) Kemampuan komunikasi matematis menghubungkan benda nyata, gambar dan diagram kedalam ide matematika. (2) Kemampuan komunikasi matematis menjelaskan idea, situasi, tulisan dengan benda nyata, gambar, grafik dan aljabar. (3) Kemampuan komunikasi matematis menyatakan peristiwa sehari-hari dalam bahasa atau simbol matematika. (4) Kemampuan komunikasi matematis membuat model dari suatu situasi melalui tulisan, benda-benda konkret, gambar, grafik, dan metode-metode aljabar. (5) Kemampuan komunikasi matematis Menjelaskan dan membuat pertanyaan tentang matematika yang telah dipelajari. Metode dalam penelitian ini menggunakan metodekualitatif. Populasi dalam penelitian ini adalah siswa kelas VIII Cimahi. Hasil penelitian menunjukkan bahwa kemampuan komunikasi matematis menghubungkan benda nyata, gambar dan diagram kedalam ide matematika tergolong rendah. Kemampuan komunikasi matematis menjelaskan idea, situasi, tulisan dengan benda nyata, gambar, grafik dan aljabar tergolong sedang. Kemampuan komunikasi matematis menyatakan peristiwa sehari-hari dalam bahasa atau simbol matematika tergolong rendah. Kemampuan komunikasi matematis membuat model dari suatu situasi melalui tulisan, benda-benda konkret, gambar, grafik, dan metode-metode aljabar tergolong rendah. Kemampuan komunikasi matematis enjelaskan dan membuat pertanyaan tentang matematika yang telah dipelajari tergolong rendah.
\end{abstract}

Kata Kunci: Komunikasi Matematis

Kemampuan komunikasi merupakan satu kemampuan dasar matematis yang esensial dan perlu dimiliki oleh siswa sekolah menengah (SM). Beberapa penulis mendefinisikan istilah komunikasi dengan cara berbeda, namun memuat pengertian yang hampir serupa. NCTM (Hendriana, Rohaeti dan Sumarmo:2017) menyatakan bahwa komunikasi matematis adalah satu kompetensi dasar matematis yang esensial dari matematika dan pendidikan matematika. Tanpa 
komunikasi yang baik, maka perkembangan matematika akan tehambat. Simbol merupakan lambang atau media yang mengandung maksud dan tujuan tertentu. Simbol komunikasi ilmiah dapat berupa tabel, bagan, grafik, gambar persamaan matematika dan sebagainya.

Pentingnya pemilikan kemampuan komunikasi matematik antara lain dikemukan Baroody (Hendriana, Soemarmo, 2014) dengan rasional a) matematika adalah bahasa esensial yang tidak hanya sebagai alat berpikir, menemukan rumus menyelesaikan masalah, atau menyimpulkan saja, namun matematika juga memiliki nilai yang tak terbatas untuk menyatakan beragam idea secara jelas, teliti dan tepat; b) matematika dan belajar matematika adalah jantungnya kegiatan sosial manusia, misalnya dalam pembelajaran matematika interaksi antara guru dan siswa, antara siswa dan siswa, antara bahan pembelajaran matematika dan siswa adalah faktor-faktor penting dalam memajukan potensi siswa.

Matematika merupakan suatu bahasa. Matematika sebagai suatu bahasa tentunya sangat diperlukan untuk dikomunikasikan baik secara lisan maupun tulisan sehingga informasi yang disampaikan dapat diketahui dan dipahami oleh orang lain. Seperti apa yang dikemukakan Cockroft (Choridah, 2013), 'We believe that all these percepcions of the usefulness of mathematics arise from the fact that mathematics provides a means of communication which is powerful, concise, and unambiguous.' Pernyataan ini menunjukkan tentang perlunya para siswa belajar matematika dengan alasan bahwa matematika merupakan alat komunikasi yang sangat kuat, teliti, dan tidak membingungkan.

Menurut Turmudi (Haerudin:2013) bahwa komunikasi adalah bagian yang essensial dari matematika dan pendidikan matematika. Bisa difahami bahwa tanpa adanya komunikasi yang baik sangat sulit bisa mengembangkan matematika sebagaimana tujuan pembelajaran yang telah ditetapkan. Hal ini karena proses komunikasi akan membantu siswa dalam membangun makna, menyampaikan gagasan dengan benar, dan memudahkan dalam menjelaskan gagasan-gagasan tersebut kepada orang lain sehingga informasinya mudah dimengerti dan dipahami. Baroody (Hendriana,dkk:2017) menyatakan ada lima aspek komunikasi matematis, yaitu merepresentasi (representating), mendengar (listening), membaca (reading), diskusi (discussing), dan menulis (writing).

Di sisi lain, Greenes dan Schulman (Umar:2012) yang menyatakan bahwa komunikasi matematik merupakan: 1) kekuata sentral bagi siswa dalam merumuskan konsep dan strategi matematik, 2) modal keberhasilan bagi siswa terhadap pendekatan dan penyelesaian dalam eksplorasi dan investigasi matematik, 3) wadah bagi siswa dalam berkomunikasi dengan temannya untuk memperoleh informasi, membagi pikiran dan penemuan, curah pendapat, menilai dan mempertajam ide untuk meyakinkan oranglain. 
Dengan demikian, kemampuan komunikasi matematis sebagai salah satu aktivitas sosial (talking) maupun sebagai alat bantu berpikir (writing) yang direkomendasikan para pakar agar terus ditumbuhkembangkan dikalangan siswa. Adapun indikator kemampuan komunikasi matematika menurut Sumarmo (dalam Yanti:2017) yaitu: 1) Menghubungkan benda nyata, gambar, dan diagram ke dalam idea matematika. 2) Menjelaskan idea, dan relasi matematik secara lisan atau tulisan dengan benda nyata, gambar, grafik dan aljabar, 3) menyatakan peristiwa sehari-hari dalam bahsa atau simbol matematika, 4) mendengarkan, berdiskusi, dan menulis tentang matematika, 5) membaca dengan pemahaman atau presentasi matematika tertulis, 6) membuat konjektur, menyusun argumen, merumuskan definisi, dan generalisasi, 7) menjelaskan dan membuat pertanyaan tentang matematika yang telah dipelajari.

\section{METODE PENELITIAN}

Untuk penelitian ini, metode yang digunakan adalah metode kualitatif. Metode ini disebut kualitatif karena lebih berdasarkan pada sifat fenomeno logis yang mengutamakan penghayatan (verstehen). Pada metode kualitatif peneliti berusaha memahami dan menafsirkan makna suatu peristiwa interaksi tingkah laku manusia dalam situasi tertentu menurut perspektif peneliti sendiri. Penelitian yang menggunakan penelitian kualitatif bertujuan untuk memahami objek yang diteliti secara mendalam.

Teknik pengambilan data pada penelitian ini dilakukan dengan menggunakan tes dalam bentuk essay dan dilakukan wawancara secara mendalam pada subyek penelitian. Teknik analisis data yang digunakan dalam penelitian ini adalah analisis deskriptif, yaitu menganalisis data dengan cara mendeskripsikan atau menggambarkan data yang telah terkumpul. Ada tiga tahapan yang dilakukan, 1) reduksi data, dalam hal ini peneliti menganalisis data dengan menganalisisjawaban siswa dibantu dengan dilakukannya wawancara untuk menentukan tahapan siswa dalam menjawab soal, 2) penyajian data, hasil analisis yang dilakukan oleh peneliti disajikan dalam bentuk teks naratif, diagram dan tabel hasil analisis, serta kesimpulan, 3) tahap kesimpulan, merupakan pengambilan kesimpulan data yang diperoleh dari proses reduksi dan penyajian data.

Menurut Sugiono (dalam Hendriana dan Afrilianto:2017) dalam penelitian kualitatif, karena permasalahan yang dibawa oleh peneliti masih bersifat sementara, maka teori yang digunakan dalam penyusunan proposal penelitian kualitatif juga masih bersifat sementara, maka teori yang digunakan dalam penyusunan proposal penelitian kualitatif juga masiih bersifat sementara, dan akan berkembang setelah peneliti memasuki lapangan atau konteks sosial. Pada penelitian kualitatif, peneliti memasuki situasi sosial tertentu, melakukan observasi dan wawancara kepada orang-orang yang dipandang tahu tentang situasi sosial tersebut. 


\section{HASIL DAN PEMBAHASAN}

Penelitian ini dilakukan pada salah satu kelas VIII di SMP Negeri 3 Ngamprah. Tes kemampuan komunikasi matematis diberikan kepada 6 siswa mengenai materi himpunan. Data dari hasil penelitian ini yaitu berupa hasil belajar siswa yang pengumpulan datanya menggunakan instrumen berupa tes uraian sebanyak 5 butir soal.

Tabel 1

Presentase Kemampuan Komunikasi Matematis

\begin{tabular}{|c|c|c|c|c|c|}
\hline Kode Siswa & $\begin{array}{c}\text { Skor Soal No } \\
1\end{array}$ & $\begin{array}{c}\text { Skor Soal No } \\
2\end{array}$ & $\begin{array}{c}\text { Skor Soal No } \\
\mathbf{3}\end{array}$ & $\begin{array}{c}\text { Skor Soal No } \\
4\end{array}$ & $\begin{array}{c}\text { Skor Soal No } \\
5\end{array}$ \\
\hline ST1 & 3 & 3 & 3 & 3 & 3 \\
\hline ST2 & 2 & 3 & 3 & 1 & 2 \\
\hline SS1 & 1 & 2 & 1 & 1 & 0 \\
\hline SS2 & 1 & 2 & 1 & 1 & 0 \\
\hline SR1 & 1 & 1 & 1 & 1 & 0 \\
\hline SR2 & 2 & 1 & 1 & 1 & 0 \\
\hline Jumlah & 10 & 12 & 10 & 8 & 5 \\
\hline Presentase & $41.7 \%$ & $50 \%$ & $41.7 \%$ & $33.3 \%$ & $20.8 \%$ \\
\hline
\end{tabular}

Berdasarkan tabel tersebut menunjukan bahwa kemampuan siswa dalam menghubungkan benda nyata, gambar dan diagram kedalam ide matematika pada soal 1 dengan presentase $41.7 \%$. Kemampuan siswa dalam menjelaskan idea secara tulisan dengan aljabar pada soal 2 dengan presentase $50 \%$. Kemampuan siswa dalam menyatakan peristiwa sehari-hari dalam bahasa atau simbol matematika pada soal no 3 dengan presentase $41.7 \%$. Kemampuan model matematis siswa dalam membuat model dari situasi melalui tulisan dan gambar pada soal no 4 dengan presentase 33.3\%. Dan kemampuan komunikasi matematis dalam menjelaskan dan membuat pertanyaan tentang matematika yang telah dipelajari pada soal no 5 dengan presentase $20.8 \%$. 
Diketahui diagram Venn berikut ini! Tentukan anggota-anggota himpunan K,L dan $\mathrm{S}$ sertahubungan apa yang terjadi antara himpunan K dan L?

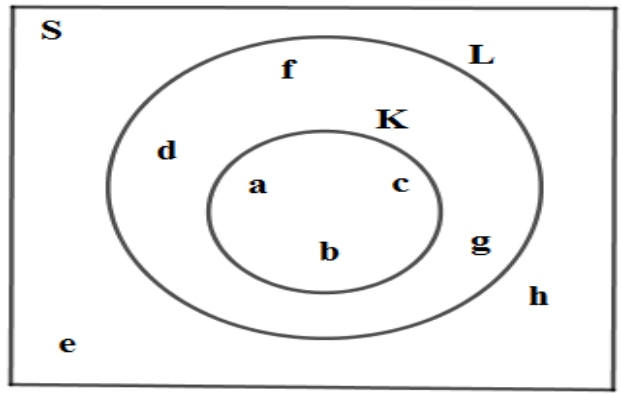

Gambar 1. Soal No.1

Analisis kemampuan komunikasi matematis subjek berkemampuan Sedang pada soal nomor 1 dipaparkan sebagaimana Gambar 1 dan Gambar 2.

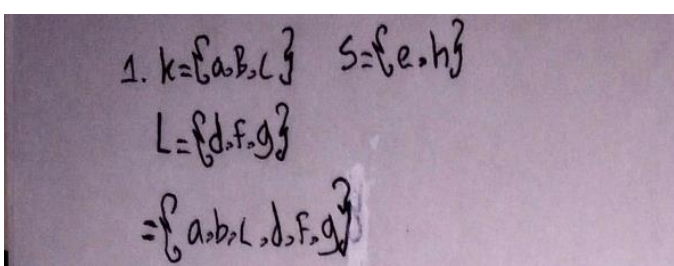

Gambar 2. Jawaban siswa SS1

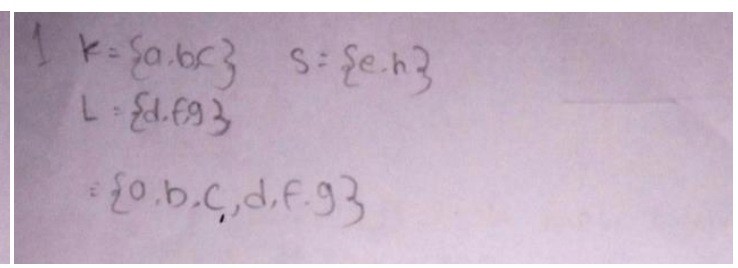

Gambar 3. Jawaban siswa SS2

Analisis kemampuan komunikasi matematis siswa SS1 pada Gambar 2. SS1 dan SS2 terlihat pada Gambar 2, SS sudah memahami apa yang diinginkan oleh soal yaitu mendaftarkan anggotaanggotanya dan menentukan hubungan yang terjadi pada himpunan tersebut, sehingga penyelesaiannya tidak terselesaikan dengan benar. Untuk memperoleh informasi lebih lanjut tentang kemampuan komunikasi matematis dilakukan percakapan terhadap siswa berkemamuan sedang, peneliti melakukan wawancara dengan SS1 dan SS2 sebagaimana transkip berikut:

P1

: Dari soal 1 apa yang ditanyakan?

SS1 dan SS2 : Menentukan anggota-anggota himpunan K,L dan S kak.

P1 : Apa kalian yakin dengan anggota-anggota himpunan yang telah kalian isi tersebut?

SS1 dan SS2 : Saya tidak tahu kak, sepertinya iya.

$\mathrm{P} 1$

:Setelah anggota-anggota himpunan sudah didapat apalagi langkah selanjutnya?

SS1 dan SS2 : Menentukan hubungan K dan L

P1 : Bagaimana cara menentukan hubungan himpunan tersebut? 
SS1 dan SS2 : Saya tidak tahu kak

P1 : Setelah itu, apakah masih ada yang harus dilakukan?

ST1 dan ST2 : Tidak ada kak.

\section{Soal No 2}

Diketahyu $S=\{$ bilangan cacah $\}, P=\{$ bilangan prima $\}$, dan $Q=\{$ bilangan ganjil $\}$. Tuliskan dengan mendaftar anggotanya, kemudian nyatakan himpunan tersebut dalam diagram venn!

Analisis kemampuan komunikasi matematis nomor 2 untuk subjek berkemampuan tinggi, sedang dan rendah hampir semua dapat memahami permasalahan yang ditanyakan oleh soal, sehingga subjek dapat mengetahui langkah-langkah untuk dapat mengilustrasikan himpunan tersebut kedalam diagram venn dan menentukan irisannya. Tetapi ada juga subjek yang berkemampuan rendah yang tidak dapat memahami persoalan tersebut dapat dilihat dari Gambar 3.
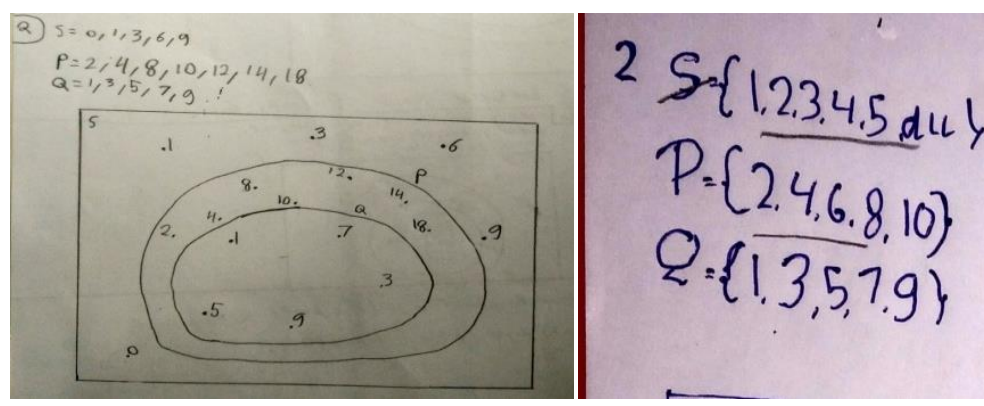

Gambar 4. Jawaban siswa SR1

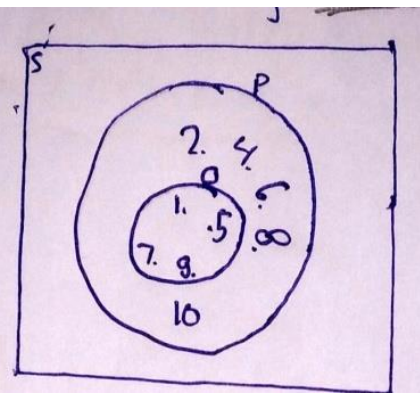

Gambar 5. Jawaban siswa SR2

Analisis kemampuan komunikasi matematis SR1 siswa tidak dapat memahami permasalahan didalam soal untuk mendaftarkan anggota-anggotanya dengan benar, ketidaktauan mereka atas anggota dari bilangan cacah, bilangan prima dan bilangan ganjil membuat proses penyelesaian tidak sesuai dengan yang diharapkan, sehingga terjadi banyak kesalahan untuk menggambarkannya didalam diagram venn.Untuk memperoleh informasi lebih lanjut tentang kemampuan komunikasi matematis SR pada nomor 2, peneliti melakukan wawancara dengan SR sebagaimana transkip tersebut.

P1 : apa yang dilakukan dengan soal nomor 2 ?

SR1 dan SR2 : menentukan anggota-anggota himpunannya kak.

P1 : apa kalian mengetahui angka-angka dari bilangan cacah, bilangan prima dan bilangan ganjil?

SR1 dan SR2 : tidak kak 
P1

: lalu apalagi yang dilakukan?

SR1

: menyatakannya didalam diagram venn kak, tapi saya tidak bisa kak membuat diagram venn-nya.

P1 : apa kamu yakin itu sudah benar diagram venn yang kamu buat?

SR1 : saya tidak yakin kak, tapi setahu saya seperti itu diagram venn-nya.

Berdasarkan wawancara peneliti dengan SR diperoleh data bahwa SR tidak memahami dan mengetahui angka-angka yang termasuk bilangan cacah, prisma dan ganjil. dan tidak mengetahui bagaimana cara membuat diagram venn. Sehingga jawabannya tidak tepat.

Analisis kesalahan-kesalahan nomor 3, 4 dan 5 untuk subjek berkemampuan tinggi, sedang dan rendah hampir semua sama tidak dapat memahami permasalahan yang ditanyakan oleh soal, sehingga subjek tidak dapat mengetahui langkah-langkah untuk dapat mengilustrasikan himpunan tersebut kedalam diagram venn dan menentukan irisannya yang terjadi pada penyelesaian tersebut. Dapat dilihat dari prentase subjek yang didapat pada soal no 3 hanya $41.7 \%$, soal no 4 hanya $33.3 \%$, dan soal no 5 hanya $20.8 \%$

\section{KESIMPULAN DAN SARAN}

Berdasarkan hasil penelitian dan pembahasan penelitian, disimpulkan bahwa kemampuan komunikasi matematis menghubungkan benda nyata, gambar dan diagram kedalam ide matematikatergolong rendah. Kemampuan komunikasi matematis menjelaskan idea, situasi, tulisan dengan benda nyata, gambar, grafik dan aljabar tergolong sedang. Kemampuan komunikasi matematis menyatakan peristiwa sehari-hari dalam bahasa atau simbol matematika tergolong rendah. Kemampuan komunikasi matematis membuat model dari suatu situasi melalui tulisan, benda-benda konkret, gambar, grafik, dan metode-metode aljabar tergolong rendah. Kemampuan komunikasi matematis menjelaskan dan membuat pertanyaan tentang matematika yang telah dipelajari tergolong rendah. Hasil ini menjadi dasar bagi peneliti-peneliti untuk melakukan penelitian lanjutan mengenai kemampuan komunikasi matematis siswa SMP di Kota Cimahi. Berdasarkan hasil penelitian yang diperoleh, peneliti memberikan saran sebagai berikut: (1) Siswa SMP hendaknya dilatih secara khusus mengenai kemampuan komunikasi matematis; (2) Diperlukan penelitian lanjutan mengenai pencapaian dan peningkatan kemampuan komunikasi matematis.

\section{DAFTAR PUSTAKA}

Choridah, D. T. (2013). Peran Pembelajaran Berbasis Masalah untuk Meningkatkan Kemampuan Komunikasi dan Berpikir Kreatif serta Disposisi Matematis Siswa SMA. Jurnal Infinity. Vol 2. No 2 . 
Haerudin. (2013). Pengaruh Pendekatan SAVI terhadap Kemampuan Komunikasi dan Penalaran Matematika Serta Kemandirian Belajar Siswa SMP. Jurnal Infinity. Vol 2. No 2 (184)

Hendriana, H. Afrilianto, M. (2017). Langkah Praktis Penelitian Tindakan Kelas bagi Guru. Bandung: PT Refika Aditama.

Hendriana, H. Rohaeti, E. E., \& Sumarmo, U. (2017). Hard Skill dan Soft Skill Matematika Siswa. Bandung: PT Refika Aditama.

Hendriana, H., Soemarmo, U. (2014). Penilaian Pembelajaran Matematika. Bandung: PT Refika Aditama.

Umar, W. (2012). Membangun Kemampuan Komunikasi Matematis dalam Pembelajaran Matematika. Jurnal Infinity. Vol 1. No 1.

Yanti. (2017). Meningkatkan Kemampuan Komunikasi Matematik Siswa SMP dengan Menggunakan Pendekatan Problem based Learning. Skripsi STKIP Siliwangi Bandung: tidak diterbitkan

Zulfah, Zulfah. Analisis Kesalahan Peserta Didik Pada Materi Persamaan Linear Dua Variabel Di Kelas Viii Mts Negeri Sungai Tonang. Jurnal Cendekia : Jurnal Pendidikan Matematika, [S.L.], V. 1, N. 1, P. 1-5, May 2017. Issn 2579-9258 